\title{
Effects of various parameters on bioenergy generation in microbial fuel cell
}

\begin{abstract}
Environmental pollution increasing day by day with increasing in industrialization apart from this researcher also investigating the techniques for controlling environmental hazards for other side energy crises get attention towards the future requirement. Microbial fuel cell had to get interested in research regarding mode of their operation and handling wastewater to best fit for environmental conditions. Pakistan has 82 distillery plants for ethanol production using fermentation process. Regarding this sludge also decanted from fermenter about 1-2 ton of each cycle of fermenter after cleaning. The main purpose of this study investigates various parameters that effects on MFC's performance.
\end{abstract}

Keywords: microbial fuel cell, electricity generation, bioenergy
Volume 7 Issue 3 - 2018

Anand Parkash
Department of Chemical Engineering, Mehran University of
Engineering \& Technology, Pakistan

Correspondence: Anand Parkash, Department of Chemical Engineering, Mehran University of Engineering \& Technology, Jamshoro, Pakistan,Email parwani_anand@yahoo.com

Received: January 24, 2018| Published: June 20, 2018

\section{Introduction}

Microbial Fuel Cells (MFCs) are a sustainable energy technology with minimal carbon footprint, which is promising for wastewater remediation and generation of useful amounts of electricity. ${ }^{1}$ Microbial Fuel Cells (MFCs) are bio-electrochemical devices whose constituent electro-active bacteria harvest electrons and protons by oxidizing organic matter. Electrons travel through the anode to the cathode electrode via an external load, and cat ions diffuse through a cat ion exchange membrane that separates the anode with the cathode. Atmospheric oxygen in the cathode reacts with the incoming electrons and protons to produce water ${ }^{2}$ Miniaturization of MFCs has been reported in the literature as a more efficient way of generating electricity ${ }^{3}$ and can be utilized for powering small devices. ${ }^{4}$ Microbial fuel cells (MFCs) can convert organic matter into electricity. In contrast to conventional fuel cells, MFCs have particular advantages such as high energy-conversion efficiency and mild reaction conditions (e.g., ambient temperature, normal pressure, and neutral $\mathrm{pH}$ ). Moreover, MFCs can convert numerous kinds of organic matters into electricity. These organic compounds include simple carbohydrates, such as glucose,${ }^{5}$ acetate and butyrate, ${ }^{6}$ and complex organic compounds such as those in swine wastewaters, ${ }^{7}$ domestic wastewater, ${ }^{8}$ and manure sludge waste generated a maximum electrical current of roughly $601 \mathrm{~A}$ and several hundred of millivolts by connecting graphite foil electrodes in an aerated aerobic zone to those in an anaerobic sludge zone. The feasibility of directly converting sewage sludge into electricity via an MFC was in part demonstrated.

\section{Results and discussion}

Bioconversion of primary fermented sludge was understudy to investigate the effects of oxygen flow rate, $\mathrm{pH}$ and concentration of sludge on electricity generation using double chamber MFC.

\section{Effect of oxygen flow rate on bioelectricity generation}

For effective treatment of sludge in the anode chamber, oxygen flow rate had effect for oxidation of proton drawn in the anode chamber. Effect of oxygen flow rate on power production during the running of MFC was studied using different oxygen flow rates from 20 to $35 \mathrm{ml} /$ min yielding in power generation between 220 and $995 \mathrm{mV}$ per liter of the primary fermented sludge treatment, respectively (Figures 1-3). These results suggested that power production increased as the air flow rate was increased and reached the maximum of around $1 \mathrm{~V}$ at oxygen flow rate of $150 \mathrm{ml} / \mathrm{min}$ before showing decline afterward. This indicates that at the higher air flow rate, power generation capacity of MFC was substantially reduced due to the higher rate of oxygen in the air diffused down to the vicinity of the anode, which probably disturbed the anaerobic microbes living on the surface of the anode.

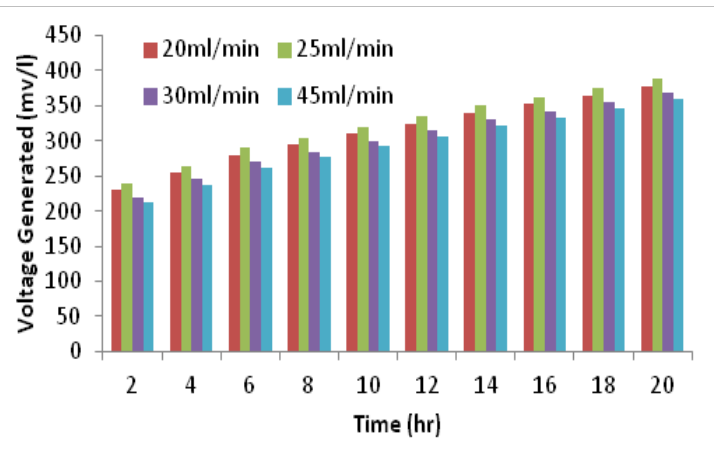

Figure 1 Effect of oxygen on power production.

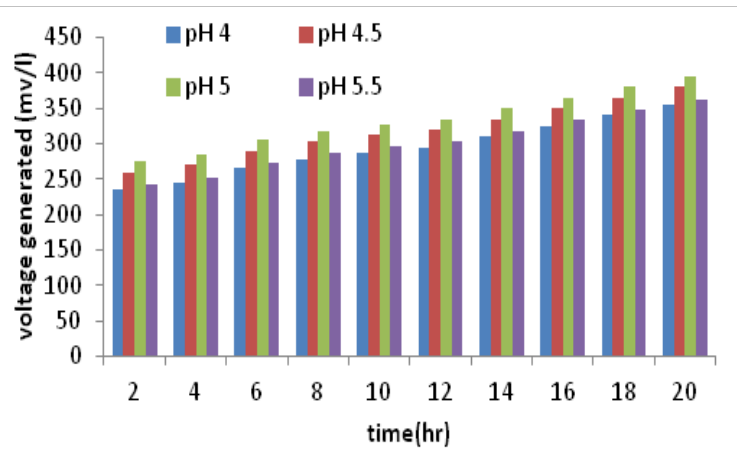

Figure 2 Effect of $\mathrm{pH}$ on power production.

\section{Effect of $\mathrm{pH}$ on power production}

$\mathrm{pH}$ is a major factor affecting the activity of most prokaryotes. At optimum $\mathrm{PH}$, microbes perform biological activities of growth and metabolism at the maximum rate. Figure 3 highlights the point that 
the highest yield of power was obtained at $\mathrm{pH} 8.5$ when perhaps the enzymes secreted by the microbes would have been in a conducive form of ionic groups on their active sites to function properly. Reportedly, variation in the $\mathrm{pH}$ would result in changes in the ionic form of the active sites, which would further change the enzymatic activity leading to the variation in the reaction rate as well. ${ }^{1}$ The results also suggested that at $\mathrm{pH} 6$ and below, electrochemical and cellulosic activities would likely be lower when compared to the results obtained at higher $\mathrm{pH}$. This might be due to the denaturation of celluloses, proteins or active sites under acidic conditions. This finding was in agreement with that reported by Z. He et al. who observed that neutral $\mathrm{pH}$ was suitable for cellulose degraders, as acidic conditions tend to inhibit the growth of most of cellulose degrading yeasts. ${ }^{2}$

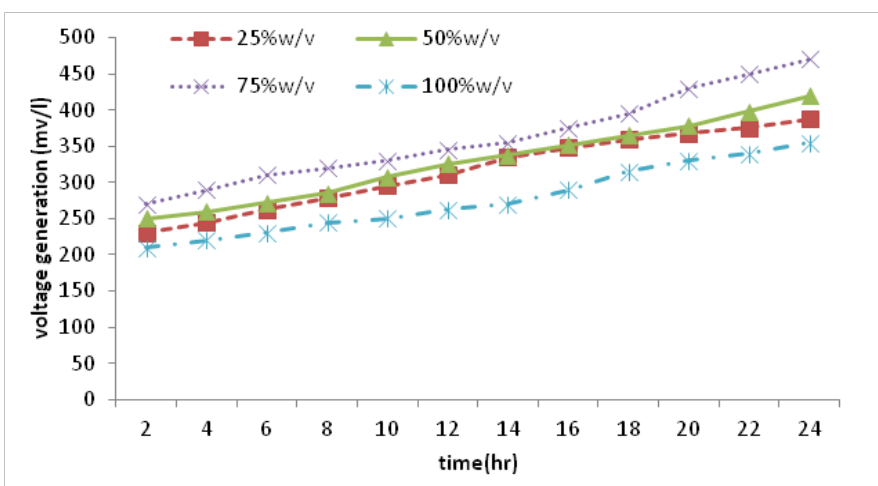

Figure 3 Effect of substrate on power production.

\section{Effect of concentration of substrate on power production}

Different concentration of primary fermented sludge was used for measuring maximum power production. Microbial fuel cell had many advantages overutilization of sludge for power generation, the effect of power production using different concentration was considered to investigate optimize condition. In fig, it is clearly highlighted that $75 \%$ suldge concentration produced maximum power generation as compare to other concentration

\section{Conclusion}

Microbial fuel cell had many advantages overutilization of primary fermented sludge it can be easily extracted out energy from primary fermented sludge by utilizing as a substrate in a microbial fuel cell with Saccharomyces cell present already in it. Different parametric effect on electricity generation was investigated.

\section{Acknowledgements}

None.

\section{Conflict of interest}

Author declares there is no conflict of interest towards this manuscript.

\section{Reference}

1. Parkash A, Aziz S, Soomro SA. Impact of Salt Concentrations on Electricity Generation using Hostel Sludge Based Duel Chambered Microbial Fuel Cell. J Bioprocess Biotech. 2015;27(2):1057-1061.

2. Shiv Kumar, Harsh Dev Kumar, Gireesh Babu K. A study on the electricity generation from the cow dung using microbial fuel cell. $J$ Biochem Tech. 2012;3(4):44-447.

3. Min B, Kim JR, Oh SE. et al. Electricity generation from swine wastewater using microbial fuel cells. Water Res. 2005;39(20):4961-4968.

4. Parkash A. Characterization of Generated Voltage, Current, Power, and Power Density from Cow Dung Using Double Chambered Microbial Fuel Cell. J Phys Chem Biophys. 6:208.

5. Scott K, Murano C. A study of a microbial fuel cell battery using manure sludge waste. J Chem Technol Biotechnol. 2007;82(9):809-817.

6. Dental SK, Strogen B, Chiu P. Direct generation of electricity from sludges and other liquid wastes. Water Sci Technol. 2004;50(9):161-168.

7. Rabaey K, Verstraete W. Microbial fuel cells: novel biotechnology for energy generation. Trends Biotechnol. 2005;23(6):291-298.

8. Parkash A. Design and Fabrication of a Double Chamber Microbial Fuel Cell for Voltage Generation from Biowaste. J Bioprocess Biotech. 2015;5:246. 